\title{
Seed biometric parameters in oil palm accessions from a Brazilian germplasm bank
}

\author{
Julcéia Camillo(1), Valentine Carpes Braga(2), Jean Kleber de Abreu Mattos ${ }^{(1)}$, Ricardo Lopes(3), \\ Raimundo Nonato Vieira da Cunha ${ }^{(3)}$, Joseane Padilha ${ }^{(4)}$ and Jonny Everson Scherwinski-Pereira(4)
}

${ }^{(1)}$ Universidade de Brasília, Campus UniversitárioDarcy Ribeiro, Faculdade de Agronomiae Medicina Veterinária, CEP70910-900 Brasília, DF, Brazil.
E-mail: julceia@gmail.com, kleber@unb.br (2)Universidade Federal do Pampa, Campus Uruguaiana, Rodovia BR 472, Km 592, CEP 97500-970
Uruguaiana, RS, Brazil. E-mail: valentine.braga@gmail.com ${ }^{(3)}$ Embrapa Amazônia Ocidental, Rodovia AM-10, Km 29, CEP 69010-970
Manaus, AM, Brazil. E-mail: ricardo.lopes@embrapa.br, raimundo.cunha@embrapa.br (4)Embrapa Recursos Genéticos e Biotecnologia,
PqEB, Avenida W5 Norte (Final), CEP 70770-917 Brasília, DF, Brazil. E-mail: joseane.padilha@embrapa.br, jonny.pereira@embrapa.br

Abstract - The objective of this work was to evaluate the morphological diversity of oil palm seeds and to cluster the accessions according to their morphological characteristics. Forty-one accessions from the oil palm germplasm bank of Embrapa Amazônia Ocidental were evaluated - 18 of Elaeis oleifera and 23 of E. guineensis. The groups were formed based on morphological characteristics, by principal component analysis. In E. oleifera, four groups were formed, tied to their region of origin, but with significant morphological differences between accessions from the same population. For tenera-type E. guineensis seeds, three widely divergent groups were formed, especially as to external parameters, which differentiated them from the other ones. The parameter endocarp thickness stood out in intra- and inter-population differentiation. For dura-type E. guineensis, three groups were formed, with larger seeds and thicker endocarps, which differed from all the other ones. The variability observed for seed characteristics in the analyzed accessions allows the establishment of different groups, to define strategies for genetic improvement.

Index terms: Elaeis guineensis, Elaeis oleifera, American oil palm, diversity, dura, tenera.

\section{Parâmetros biométricos de sementes de acessos de palma de óleo de banco de germoplasma brasileiro}

Resumo - O objetivo deste trabalho foi avaliar a diversidade morfológica de sementes de palma de óleo e agrupar os acessos de acordo com as suas características morfológicas. Foram avaliados 41 acessos do banco de germoplasma de palma de óleo da Embrapa Amazônia Ocidental - 18 de Elaeis oleifera e 23 de E. guineensis. Os agrupamentos foram formados com base em características morfológicas, por meio de análise de componentes principais. Em E. oleifera, foram formados quatro grupos ligados às suas regiões de origem, mas com diferenças morfológicas significativas entre acessos de uma mesma população. Para sementes de E. guineensis do tipo tenera, foram formados três grupos bastante divergentes, especialmente quanto aos parâmetros externos, os quais os diferenciaram dos demais. O parâmetro espessura do endocarpo se destacou na diferenciação intra e interpopulacional. Para E. guineensis do tipo dura, houve a formação de três grupos, com sementes maiores e endocarpos mais espessos, que diferiram dos demais. A variabilidade observada para as características das sementes, nos acessos analisados, permite estabelecer grupos divergentes, para definição de estratégias de melhoramento genético.

Termos para indexação: Elaeis guineensis, Elaeis oleifera, palma de óleo americana, diversidade, dura, tenera.

\section{Introduction}

Oil palm (Elaeis guineensis Jacq.), a palm of African origin, is the world's leading source of vegetable oil (Food and Agriculture Organization of the United Nations, 2012). The species has a native relative from Central America and northern South America - E. oleifera (Kunth) Cortés - with which it is crossbred to produce fertile offspring. Despite their morphological similarities, these two species also have distinct characteristics, such as oil quality and growth height. Elaeis oleifera is a small-sized plant, facilitating harvest and cultural practices, that has superior oil quality, which is attributed to the higher concentration of unsaturated fatty acids ( $78 \%$ ) in the species, resulting in a more fluid oil at room temperature. Due to its qualities, E. oleifera has been incorporated into the breeding program of oil palm, originating productive

Pesq. agropec. bras., Brasília, v.49, n.8, p.604-612, ago. 2014

DOI: 10.1590/S0100-204X2014000800004 
interspecific hybrids (E. guineensis x E. oleifera), characterized by reduced height, which increases the period of economic exploitation of the culture, and especially by resistance to oil palm bud rot, the most important disease of the continent (Cunha et al., 2012; Moreno-Chacón et al., 2013; Gomes Junior et al., 2014).

However, for effective results in genetic improvement, the knowledge of intraspecific genetic variability is essential. In oil palm, morphological aspects of fruits and seeds can directly influence both oil production and its spread. Seed morphology can provide information on germination and dormancy, caused by, for example, an impermeable tegument or by the immaturity of the embryo. Additionally, proportions between endocarp and kernels, as well as measurements of fruit sphericity, are important parameters for the development of machines for oil palm processing (Fondom et al., 2010; Myint et al., 2010; Akinoso \& Raji, 2011). In genetic improvement, the variability in seed parameters can be used in the study of intra- and interspecies relationships to provide data about genetic similarity and to establish divergent groups for selection in crossbreeding. Knowing the interaction between species and environmental factors, and the correlation with the productive potential of each accession is also fundamental (Christro et al., 2012).

The fruit of the oil palm is composed of four layers: the exocarp (skin), the mesocarp (pulp), the endocarp (shell), and the endosperm (kernel); together, the last two form the seed, with an adhering endocarp. Oil palm, or the African oil palm, presents great phenotypic variation in fruits. It is possible to distinguish three types of plants according to the presence and thickness of the endocarp: pisifera, which produces fruits without the endocarp; dura, with an endocarp with a thickness exceeding $2 \mathrm{~mm}$; and tenera, with an endocarp less than $2 \mathrm{~mm}$ thick. In E. oleifera, only the dura type occurs, but studies report the existence of a great variety in fruit size and color (Cunha et al., 2012; Rios et al., 2012; Montoya et al., 2014).

There are few researches on the species E. oleifera. Data on its genetic diversity are described by Rios et al. (2011), based on biometric measurements of rachi length, number of leaflets, leaflet length and width, petiole length, and stem length. Multivariate analyses of clusters and graphical dispersion revealed the existence of variability within accessions and succeeded in discriminating them. Okwuagwu et al.
(2008) quantified the genetic variability of the African oil palm by analysis of agronomic traits, including number of fruit clusters, average cluster weight, and fruit yield. These authors identified significant differences between the assessed genotypes.

The objective of this work was to evaluate the morphological diversity of oil palm seeds and to cluster the accessions according to their morphological characteristics.

\section{Materials and Methods}

The evaluated materials were collected from the active oil palm germplasm bank of Embrapa Amazônia Ocidental, located at the Experimental Campus of Rio Urubu, in the municipality of Rio Preto da Eva, in the state of Amazonas, Brazil. The fresh fruits that originated the seeds were collected in January 2010; the pulp was removed through a machine, in order to extract the seeds from the mesocarps, which were immediately transported to the experimental area. A total of 820 seeds from 41 accessions (20 seeds per accession) were used in the study. Of the 41 accessions, 18 were of E. oleifera and 23 of E. guineensis. Of the E. guineensis accessions, 11 were of the tenera type and 12 of the dura type (Table 1).

Measurements were made on 20 seeds from each of the 41 accessions. The following parameters were recorded: longitudinal seed diameter (LDD), considered the greatest longitudinal axis; transverse seed diameter (TDD), which is the greatest transverse axis; endocarp thickness (ET); kernel weight (KW); longitudinal kernel diameter (LDK), considered the greatest longitudinal axis; transverse, which is the greatest transverse axis; kernel diameter (TDK); number of kernels per seed (NK); and embryo length (ES).

Weight was measured using a precision analytical balance, and diameter was measured using digital calipers. To measure endocarp thickness, kernel size and weight, and embryo size, the endocarp was removed after breaking by mechanical pressure.

The collected data were subjected to descriptive statistical analysis, for which the mean, standard deviation, and coefficient of variation (CV) were calculated. Means were compared by the test, at 5\% probability, and the homogeneity of the variances of the treatments was verified by Hartley's F-max test, at $5 \%$ probability.

Pesq. agropec. bras., Brasília, v.49, n.8, p.604-612, ago. 2014 DOI: $10.1590 / \mathrm{S} 0100-204 X 2014000800004$ 
In multivariate analyses, the data were partitioned (clustered) into $\mathrm{k}$ clusters around medoids (a more robust version of K-means) by the partitioning around medoids (PAM) algorithm and were validated by the silhouette method. After grouping of accessions by the cluster analysis, principal component analysis (PCA) was carried out in order to determine

Table 1. Evaluated Elaeis oleifera and E. guineensis accessions.

\begin{tabular}{|c|c|c|c|}
\hline Accessions & & Type & Origin \\
\hline \multicolumn{4}{|l|}{ E. oleifera } \\
\hline EOD01 & A312902 & dura & Manicoré-Rio Madeira \\
\hline EOD02 & A313020 & dura & Manicoré-Rio Madeira \\
\hline EOD03 & A313516 & dura & Manicoré-Rio Madeira \\
\hline EOD04 & A410213 & dura & Manicoré-Democracia \\
\hline EOD05 & A410312 & dura & Manicoré-Democracia \\
\hline EOD06 & A410507 & dura & Manicoré-Igarapé-Açu \\
\hline EOD07 & A410517 & dura & Manicoré-Liberdade \\
\hline EOD08 & A410610 & dura & Manicoré-Democracia \\
\hline EOD09 & A440320 & dura & Moura-E. Caburis \\
\hline EOD10 & A440322 & dura & Moura-E. Caburis \\
\hline EOD11 & A440805 & dura & Careiro-Iranduba/Transcal \\
\hline EOD12 & A440902 & dura & Careiro-Iranduba/Transcal \\
\hline EOD13 & A440906 & dura & Careiro-Iranduba/Transcal \\
\hline EOD14 & A510715 & dura & Careiro-Igarapé Tapajós \\
\hline EOD15 & A510726 & dura & Autazes-Nova Esperança \\
\hline EOD16 & A511014 & dura & Amatari-Alambique \\
\hline EOD17 & A510833 & dura & Careiro-Caldeirão \\
\hline EOD18 & A510528 & dura & Amatari-Alambique \\
\hline \multicolumn{4}{|c|}{ E. guineensis } \\
\hline EGT01 & A441606 & tenera & Angola \\
\hline EGT02 & A441907 & tenera & Yangambi \\
\hline EGT03 & A442003 & tenera & Yangambi \\
\hline EGT04 & A442120 & tenera & Ivory Coast \\
\hline EGT05 & A544029 & tenera & Pobé \\
\hline EGT06 & A545029 & tenera & Nigeria-Aba-Calabar \\
\hline EGT07 & A545229 & tenera & Nigeria-Aba-Calabar \\
\hline EGT08 & A630315 & tenera & Nigeria \\
\hline EGT09 & A630525 & tenera & Cameroon \\
\hline EGT10 & A630913 & tenera & Congo \\
\hline EGT11 & A630920 & tenera & Congo \\
\hline EGD01 & A401210 & dura & Bahia \\
\hline EGD02 & A401304 & dura & Bahia \\
\hline EGD03 & A401402 & dura & Bahia \\
\hline EGD04 & A442204 & dura & Deli-Dabou \\
\hline EGD05 & A442220 & dura & Deli-Dabou \\
\hline EGD06 & A442514 & dura & Deli-Dabou \\
\hline EGD07 & A542221 & dura & Yocoboe \\
\hline EGD08 & A542223 & dura & Yocoboe \\
\hline EGD09 & A542526 & dura & Ivory Coast \\
\hline EGD10 & A630207 & dura & Nigeria \\
\hline EGD11 & A630222 & dura & Nigeria \\
\hline EGD12 & A630304 & dura & Nigeria \\
\hline
\end{tabular}

discriminating morphological characteristics, as well as the correlations between them. Statistical analyses were performed using the $\mathrm{R}$ statistical programming language (R Development Core Team, 2013).

\section{Results and Discussion}

For the accessions of E. oleifera, the parameters that showed the greatest variation were KW, with a $\mathrm{CV}$ of $31.9 \%$, and seed weight (DW), with a CV of $20.7 \%$ (Table 2). These parameters also presented the greatest variation for tenera-type E. guineensis, with CV of $36.9 \%$ for KW and of $39.3 \%$ for DW. For these accessions, significant variation in endocarp thickness was also observed, with CV of $35 \%$. Accessions of dura-type E. guineensis showed high variation for DW, with CV of $31.5 \%$, and for $\mathrm{KW}$, with CV of $40.4 \%$, but moderate variation for number of kernels $(\mathrm{CV}=27 \%)$, embryo size $(\mathrm{CV}=23.4 \%)$, and endocarp thickness $(\mathrm{CV}=20 \%)$.

Considering the seed biometric measures subjected to multivariate analyses, clustering methods showed the formation of four groups (optimal number) for the species E. oleifera, and of three groups for tenera- and dura-type E. guineensis (Table 3).

The evaluation of internal parameters showed that, in all the accessions of E. oleifera, endocarp thickness was greater than $2 \mathrm{~mm}$ (Table 2). With few exceptions, most of the seeds were unilocular with a single kernel. The predominant characteristic of the kernels of this species is their ovoid form, given that LDD was greater than TDD in all accessions. The EOD09 and EOD10 accessions, both from the municipality of Moura, in the state of Amazonas, Brazil, had the largest embryos, measuring 3.3 e $3.4 \mathrm{~mm}$, respectively. These accessions also had the heaviest kernels, weighing 1.4 and $1.6 \mathrm{~g}$, respectively.

Cluster analyses for $E$. oleifera revealed that the proportion of total variability in the first two components is $68.8 \%$. The first component shows a direct correlation among seed weight, kernel weight, and kernel diameters (transverse and longitudinal); these variables are indirectly related to the number of loci and to the number of kernels (Table 4). In terms of accessions, this contrast differentiates groups $\mathrm{D}$ and $\mathrm{B}$ from each other. The second component shows a direct relationship between number of loci and number of kernels, highlighting group $\mathrm{B}$, which has lower values for these variables (Figure 1). 
Table 2. Descriptive statistics of Elaeis oleifera and tenera- and dura-type E. guineensis seeds ${ }^{(1)}$.

\begin{tabular}{|c|c|c|c|c|c|c|c|c|c|}
\hline Accessions & DW (g) & TDD (mm) & LDD (mm) & $\mathrm{ET}(\mathrm{mm})$ & NK (unit) & TDK (mm) & LDK (mm) & $\mathrm{ES}(\mathrm{mm})$ & $\mathrm{KW}(\mathrm{g})$ \\
\hline \multicolumn{10}{|l|}{ E. oleifera } \\
\hline EOD01 & $4.4 \pm 1.0$ & $18.6 \pm 1.8$ & $22.0 \pm 2.2$ & $2.8 \pm 0.4$ & $1.1 \pm 0.3$ & $12.3 \pm 1.5$ & $14.7 \pm 2.1$ & $2.5 \pm 0.9$ & $1.0 \pm 0.3$ \\
\hline EOD02 & $3.5 \pm 0.7$ & $17.4 \pm 2.1$ & $20.6 \pm 2.1$ & $2.7 \pm 0.4$ & $1.0 \pm 0.0$ & $11.4 \pm 1.9$ & $13.4 \pm 1.8$ & $1.9 \pm 0.9$ & $0.7 \pm 0.2$ \\
\hline EOD03 & $3.6 \pm 0.6$ & $17.3 \pm 1.7$ & $19.2 \pm 2.2$ & $2.7 \pm 0.3$ & $1.0 \pm 0.0$ & $11.8 \pm 0.9$ & $12.9 \pm 1.6$ & $2.3 \pm 0.7$ & $0.8 \pm 0.2$ \\
\hline EOD04 & $2.7 \pm 0.3$ & $14.4 \pm 1.9$ & $19.8 \pm 1.5$ & $2.4 \pm 0.3$ & $1.0 \pm 0.0$ & $9,4 \pm 1.5$ & $12.6 \pm 1.1$ & $2.7 \pm 0.6$ & $0.6 \pm 0.1$ \\
\hline EOD05 & $2.3 \pm 0.4$ & $13.9 \pm 1.3$ & $18.9 \pm 1.8$ & $2.2 \pm 0.3$ & $1.0 \pm 0.0$ & $9.6 \pm 1.5$ & $13.3 \pm 1.2$ & $2.3 \pm 0.6$ & $0.6 \pm 0.1$ \\
\hline EOD06 & $3.0 \pm 0.7$ & $13.9 \pm 1.5$ & $19.9 \pm 2.0$ & $2.5 \pm 0.3$ & $1.0 \pm 0.0$ & $10.6 \pm 1.7$ & $13.2 \pm 2.1$ & $2.7 \pm 0.7$ & $0.7 \pm 0.2$ \\
\hline EOD07 & $3.8 \pm 1.1$ & $18.7 \pm 2.4$ & $21.3 \pm 2.7$ & $2.5 \pm 0.4$ & $1.2 \pm 0.4$ & $12.4 \pm 1.6$ & $14.3 \pm 1.4$ & $2.5 \pm 0.6$ & $0.9 \pm 0.2$ \\
\hline EOD08 & $3.2 \pm 0.7$ & $17.5 \pm 2.0$ & $22.0 \pm 2.6$ & $2.4 \pm 0.4$ & $1.2 \pm 0.4$ & $10.4 \pm 1.2$ & $14.0 \pm 1.8$ & $1.9 \pm 0.4$ & $0.6 \pm 0.1$ \\
\hline EOD09 & $4.3 \pm 0.8$ & $17.8 \pm 2.0$ & $22.4 \pm 1.4$ & $2.3 \pm 0.4$ & $1.0 \pm 0.0$ & $12.7 \pm 1.7$ & $15.3 \pm 2.0$ & $3.3 \pm 0.6$ & $1.4 \pm 0.4$ \\
\hline EOD10 & $5.0 \pm 0.8$ & $18.2 \pm 2.0$ & $21.7 \pm 1.7$ & $2.7 \pm 0.3$ & $1.0 \pm 0.0$ & $11.9 \pm 1.6$ & $15.9 \pm 1.7$ & $3.4 \pm 0.5$ & $1.6 \pm 0.3$ \\
\hline EOD11 & $3.3 \pm 1.1$ & $18.2 \pm 2.5$ & $19.6 \pm 1.8$ & $2.2 \pm 0.3$ & $1.1 \pm 0.3$ & $11.4 \pm 1.4$ & $12.9 \pm 1.7$ & $2.8 \pm 0.4$ & $0.8 \pm 0.2$ \\
\hline EOD12 & $3.5 \pm 0.8$ & $17.1 \pm 2.0$ & $21.0 \pm 1.6$ & $2.5 \pm 0.5$ & $1.1 \pm 0.3$ & $10.8 \pm 1.6$ & $13.8 \pm 1.5$ & $2.6 \pm 0.6$ & $0.8 \pm 0.2$ \\
\hline EOD13 & $3.1 \pm 0.6$ & $16.5 \pm 1.7$ & $20.9 \pm 2.7$ & $2.2 \pm 0.4$ & $1.0 \pm 0.0$ & $11.4 \pm 1.6$ & $13.9 \pm 2.0$ & $2.9 \pm 0.6$ & $0.8 \pm 0.2$ \\
\hline EOD14 & $2.6 \pm 0.6$ & $14.6 \pm 1.7$ & $20.0 \pm 1.4$ & $2.2 \pm 0.3$ & $1.3 \pm 0.6$ & $9.6 \pm 1.1$ & $13.0 \pm 0.9$ & $1.8 \pm 0.4$ & $0.6 \pm 0.1$ \\
\hline EOD15 & $4.4 \pm 1.0$ & $16.6 \pm 1.9$ & $23.1 \pm 1.6$ & $2.3 \pm 0.3$ & $1.1 \pm 0.2$ & $11.8 \pm 2.0$ & $15.3 \pm 2.3$ & $2.7 \pm 0.8$ & $1.2 \pm 0.4$ \\
\hline EOD16 & $4.4 \pm 0.9$ & $18.9 \pm 2.2$ & $22.0 \pm 2.9$ & $3.0 \pm 0.4$ & $1.0 \pm 0.0$ & $12.0 \pm 1.8$ & $14.7 \pm 2.9$ & $2.3 \pm 0.4$ & $0.9 \pm 0.3$ \\
\hline EOD17 & $3.0 \pm 0.5$ & $16.7 \pm 1.6$ & $20.0 \pm 1.4$ & $2.4 \pm 0.3$ & $1.0 \pm 0.0$ & $11.3 \pm 1.7$ & $12.9 \pm 1.2$ & $2.7 \pm 0.5$ & $0.8 \pm 0.2$ \\
\hline EOD18 & $3.7 \pm 0.8$ & $21.9 \pm 2.2$ & $17.1 \pm 2.4$ & $2.3 \pm 0.3$ & $1.0 \pm 0.0$ & $11.4 \pm 2.4$ & $15.8 \pm 1.3$ & $2.2 \pm 0.5$ & $1.0 \pm 0.3$ \\
\hline Mean & 3.5 & 17.1 & 20.6 & 2.5 & 1.1 & 11.2 & 14.0 & 2.5 & 0.9 \\
\hline CV (\%) & 20.7 & 11.8 & 7.2 & 9.6 & 8.6 & 8.7 & 7.6 & 17.4 & 31.9 \\
\hline \multicolumn{10}{|c|}{ E. guineensis - tenera type } \\
\hline EGT01 & $1.3 \pm 0.3$ & $12.4 \pm 1.4$ & $16.9 \pm 2.4$ & $0.7 \pm 0.1$ & $1.3 \pm 0.4$ & $10.6 \pm 1.5$ & $13.7 \pm 1.6$ & $2.8 \pm 0.6$ & $0.7 \pm 0.2$ \\
\hline EGT02 & $1.4 \pm 0.2$ & $13.3 \pm 0.8$ & $16.4 \pm 1.0$ & $0.8 \pm 0.2$ & $1.1 \pm 0.2$ & $11.5 \pm 0.7$ & $12.6 \pm 0.8$ & $2.8 \pm 0.6$ & $0.8 \pm 0.1$ \\
\hline EGT03 & $1.3 \pm 0.2$ & $14.2 \pm 2.4$ & $15.6 \pm 1.5$ & $0.5 \pm 0.1$ & $2.0 \pm 0.4$ & $9.9 \pm 0.8$ & $12.1 \pm 0.8$ & $2.5 \pm 0.5$ & $0.4 \pm 0.1$ \\
\hline EGT04 & $0.6 \pm 0.2$ & $10.4 \pm 1.1$ & $16.2 \pm 2.6$ & $0.9 \pm 0.2$ & $1.0 \pm 0.0$ & $8.1 \pm 0.9$ & $9.3 \pm 0.9$ & $2.5 \pm 0.8$ & $0.3 \pm 0.1$ \\
\hline EGT05 & $1.1 \pm 0.3$ & $12.5 \pm 1.6$ & $16.6 \pm 1.2$ & $0.7 \pm 0.2$ & $1.6 \pm 0.7$ & $9.2 \pm 1.0$ & $12.0 \pm 1.5$ & $2.7 \pm 0.5$ & $0.4 \pm 0.1$ \\
\hline EGT06 & $0.7 \pm 0.2$ & $10.2 \pm 1.4$ & $14.0 \pm 1.1$ & $0.8 \pm 0.1$ & $1.0 \pm 0.0$ & $8.7 \pm 1.5$ & $11.4 \pm 1.1$ & $2.7 \pm 0.7$ & $0.5 \pm 0.2$ \\
\hline EGT07 & $0.6 \pm 0.2$ & $9.9 \pm 1.3$ & $12.0 \pm 1.1$ & $0.4 \pm 0.1$ & $1.0 \pm 0.0$ & $8.8 \pm 1.3$ & $10.7 \pm 1.1$ & $3.0 \pm 0.4$ & $0.4 \pm 0.1$ \\
\hline EGT08 & $1.1 \pm 0.3$ & $11.1 \pm 1.2$ & $13.9 \pm 1.6$ & $0.8 \pm 0.1$ & $1.7 \pm 0.5$ & $9.5 \pm 1.1$ & $10.8 \pm 1.2$ & $2.3 \pm 0.4$ & $0.8 \pm 0.1$ \\
\hline EGT09 & $0.5 \pm 0.2$ & $10.1 \pm 1.9$ & $11.6 \pm 1.1$ & $0.4 \pm 0.1$ & $1.4 \pm 0.5$ & $7.8 \pm 0.6$ & $9.3 \pm 0.9$ & $2.7 \pm 0.7$ & $0.3 \pm 0.0$ \\
\hline EGT10 & $1.4 \pm 0.2$ & $13.1 \pm 1.4$ & $15.5 \pm 1.2$ & $0.7 \pm 0.2$ & $2.0 \pm 0.3$ & $10.0 \pm 0.9$ & $11.7 \pm 1.0$ & $2.1 \pm 0.4$ & $0.4 \pm 0.1$ \\
\hline EGT11 & $0.5 \pm 0.1$ & $9.7 \pm 1.3$ & $9.8 \pm 0.8$ & $0.2 \pm 0.1$ & $1.0 \pm 0.0$ & $9.6 \pm 0.9$ & $9.6 \pm 1.0$ & $2.7 \pm 0.6$ & $0.5 \pm 0.1$ \\
\hline Mean & 1.0 & 11.5 & 14.4 & 0.6 & 1.4 & 9.4 & 11.2 & 2.6 & 0.5 \\
\hline CV (\%) & 39.3 & 13.9 & 16.4 & 35.0 & 29.0 & 11.4 & 12.7 & 9.6 & 36.9 \\
\hline \multicolumn{10}{|c|}{ E. guineensis - dura type } \\
\hline EGD01 & $4.6 \pm 1.3$ & $15.9 \pm 2.7$ & $26.0 \pm 3.6$ & $2.1 \pm 0.4$ & $1.3 \pm 0.6$ & $12.9 \pm 1.4$ & $17.5 \pm 1.9$ & $2.9 \pm 0.7$ & $1.2 \pm 0.3$ \\
\hline EGD02 & $4.6 \pm 0.8$ & $18.1 \pm 1.3$ & $26.8 \pm 3.4$ & $2.7 \pm 0.5$ & $1.0 \pm 0.0$ & $12.4 \pm 0.9$ & $15.8 \pm 1.2$ & $3.1 \pm 0.8$ & $1.1 \pm 0.1$ \\
\hline EGD03 & $4.7 \pm 1.3$ & $18.3 \pm 3.0$ & $21.5 \pm 3.3$ & $2.6 \pm 0.4$ & $1.4 \pm 0.5$ & $11.7 \pm 1.5$ & $12.8 \pm 2.1$ & $2.9 \pm 0.6$ & $1.0 \pm 0.2$ \\
\hline EGD04 & $5.5 \pm 1.0$ & $20.7 \pm 1.8$ & $25.8 \pm 3.6$ & $2.8 \pm 0.3$ & $1.1 \pm 0.2$ & $14.6 \pm 1.7$ & $17.0 \pm 1.9$ & $2.4 \pm 0.6$ & $1.5 \pm 0.3$ \\
\hline EGD05 & $2.9 \pm 0.7$ & $16.0 \pm 2.2$ & $21.4 \pm 2.7$ & $1.9 \pm 0.3$ & $1.1 \pm 0.3$ & $11.5 \pm 1.3$ & $14.6 \pm 1.7$ & $2.3 \pm 0.5$ & $0.9 \pm 0.2$ \\
\hline EGD06 & $3.0 \pm 0.5$ & $16.3 \pm 1.6$ & $23.9 \pm 3.5$ & $1.7 \pm 0.2$ & $1.2 \pm 0.4$ & $11.7 \pm 0.9$ & $13.8 \pm 1.0$ & $2.5 \pm 0.8$ & $0.9 \pm 0.2$ \\
\hline EGD07 & $2.8 \pm 1.0$ & $15.3 \pm 1.7$ & $23.2 \pm 4.5$ & $2.3 \pm 0.4$ & $1.0 \pm 0.0$ & $9.6 \pm 1.0$ & $12.4 \pm 2.3$ & $2.0 \pm 0.0$ & $0.5 \pm 0.1$ \\
\hline EGD08 & $2.4 \pm 0.7$ & $15.6 \pm 2.3$ & $18.5 \pm 3.1$ & $2.0 \pm 0.4$ & $1.3 \pm 0.6$ & $9.3 \pm 1.3$ & $11.8 \pm 2.1$ & $1.8 \pm 0.4$ & $0.5 \pm 0.1$ \\
\hline EGD09 & $2.3 \pm 0.4$ & $15.6 \pm 1.7$ & $19.6 \pm 2.2$ & $1.6 \pm 0.3$ & $2.3 \pm 0.6$ & $8.7 \pm 0.9$ & $10.7 \pm 0.7$ & $1.2 \pm 0.4$ & $0.3 \pm 0.1$ \\
\hline EGD10 & $2.5 \pm 0.5$ & $15.1 \pm 2.0$ & $22.3 \pm 2.9$ & $1.5 \pm 0.3$ & $1.5 \pm 0.5$ & $10.3 \pm 0.9$ & $15.1 \pm 1.8$ & $2.2 \pm 0.5$ & $0.7 \pm 0.2$ \\
\hline EGD11 & $3.4 \pm 0.9$ & $16.8 \pm 2.1$ & $25.3 \pm 3.9$ & $2.3 \pm 0.4$ & $1.1 \pm 0.2$ & $10.2 \pm 1.0$ & $15.6 \pm 2.2$ & $2.2 \pm 0.5$ & $0.7 \pm 0.2$ \\
\hline EGD12 & $2.8 \pm 0.9$ & $15.3 \pm 2.0$ & $20.2 \pm 2.8$ & $2.0 \pm 0.4$ & $1.3 \pm 0.5$ & $10.5 \pm 1.2$ & $14.2 \pm 1.1$ & $3.0 \pm 0.6$ & $0.7 \pm 0.1$ \\
\hline Mean & 3.5 & 16.6 & 22.9 & 2.1 & 1.3 & 11.1 & 14.3 & 2.4 & 0.8 \\
\hline CV (\%) & 31.5 & 10.1 & 11.9 & 20.1 & 27.0 & 15.1 & 14.6 & 23.4 & 40.4 \\
\hline
\end{tabular}

${ }^{(1)} \mathrm{DW}$, seed weight; TDD, transversal seed diameter; LDD, longitudinal seed diameter; ET, endocarp thickness; NK, number of kernels; TDK, transversal kernel diameter; LDK, longitudinal kernel diameter; ES, embryo size; KW, kernel weight. 
Studies of the biometry of E. oleifera seeds indicate variability within the species. Rios et al. (2011) reported that accessions of E. oleifera collected in the region of Coari, in the state of Amazonas, and maintained in the germplasm bank of Embrapa showed phenotypic variability, and that the characteristics that most influenced plant differentiation were rachi and petiole length, besides stem height. Rey B. et al. (2004), when evaluating populations of E. oleifera, observed large genetic variability in fruit weight and in pulp percentage in fruits from ten populations.

In a study using molecular markers, Moretzsohn et al. (2002) evaluated 45 accessions of E. oleifera from the municipality of Manicoré, in the state of Amazonas, and found that $84 \%$ of them were allocated to the same group; of the total number of accessions, $70 \%$ are from areas known as anthropogenic dark

Table 3. Cluster obtained by the unweighted pair group method with arithmetic mean (UPGMA) according to seed biometric parameters.

\begin{tabular}{lccc}
\hline Cluster & $\begin{array}{c}\text { Elaeis } \\
\text { oleifera }\end{array}$ & $\begin{array}{c}\text { E. guineensis }- \\
\text { tenera type }\end{array}$ & $\begin{array}{c}\text { E. guineensis - } \\
\text { dura type }\end{array}$ \\
\hline A & EOD18 & $\begin{array}{c}\text { EGT11, EGT07, } \\
\text { EGT09 }\end{array}$ & $\begin{array}{c}\text { EGD04, EGD11, } \\
\text { EGD01, EGD02 }\end{array}$ \\
\hline B & EOD04, EOD05, & $\begin{array}{c}\text { EGT01, EGT02, } \\
\text { EGT03, EGT05, } \\
\text { EOD06, EOD14 }\end{array}$ & EGD08, EGD09 \\
& EGT10 & \\
C & EOD02, EOD03, & EGT04, EGT06, & EGD03, EGD10, \\
& EOD11, EOD12, & EGT08 & EGD06, EGD07 \\
\hline & EOD13, EOD17 & & \\
EOD01, EOD07, & & \\
& EOD08, EOD09, & & \\
& EOD10, EOD15, \\
EOD16
\end{tabular}

earth, which are fertile and carbon-rich soils found throughout the Amazonia region (Lehmann, 2009). In the present study, the accessions were clustered according to their morphological characteristics. Eleven accessions from Manicoré origin resulted in three distinct groups, highlighting the great variability in this source area. Group $\mathrm{C}$ included most of the individuals, from the Manicoré-Rio Madeira (EOD03, EOD02), Manicoré-Rio Matupiri (EOD11, EOD13), and Manicoré-Atininga (EOD12) accessions. Considerable differences were observed between the Manicoré-Democracia accessions, which were divided into two groups. The EOD05 and EOD04 accessions of Manicoré-Democracia origin remained in group A, clustered with the Manicoré-Igarapé-Açu accession. Group D included the EOD10 and the EOD08 accessions from Moura and Manicoré-Democracia origin, respectively, grouped with two other accessions from the same population, EOD07 from ManicoréLiberdade and EOD01 from Manicoré-Rio Madeira. The latter differed from the other two accessions of the same origin, which were clustered with the Manicore accessions in group $\mathrm{C}$.

This approximation between individuals from different groups is probably related to the constant gene flow among populations, which, in this case, may be caused primarily by anthropic action, since the occurrence of natural populations of the species is strongly linked to the presence of human populations, especially indigenous peoples; and by water flow, as E. oleifera plants grow predominantly next to the course of the Amazonian rivers, the seeds can float in the water and disperse more easily (Moretzsohn et al., 2002).

Table 4. Weighting coefficients of Elaeis oleifera and tenera- and dura-type E. guineensis seeds in the first two principal components (PC1 and PC2).

\begin{tabular}{|c|c|c|c|c|c|c|}
\hline \multirow[t]{2}{*}{ Variables } & \multicolumn{2}{|c|}{ E. oleifera } & \multicolumn{2}{|c|}{ E. guineensis - tenera type } & \multicolumn{2}{|c|}{ E. guineensis - dura type } \\
\hline & CP1 & CP2 & CP1 & $\mathrm{CP} 2$ & CP1 & $\mathrm{CP} 2$ \\
\hline Seed weight & -0.946 & -0.251 & -0.990 & 0.077 & -0.900 & 0.382 \\
\hline Transversal seed diameter & -0.642 & -0.299 & -0.934 & -0.037 & -0.760 & 0.502 \\
\hline Longitudinal seed diameter & -0.474 & -0.464 & -0.788 & 0.124 & -0.813 & -0.059 \\
\hline Endocarp thickness & -0.455 & 0.031 & -0.521 & 0.054 & -0.790 & 0.110 \\
\hline Kernel weight & 0.450 & -0.873 & -0.671 & -0.683 & 0.730 & 0.634 \\
\hline Transversal kernel diameter & -0.866 & -0.158 & -0.722 & 0.523 & -0.919 & 0.222 \\
\hline Longitudinal kernel diameter & -0.820 & -0.255 & -0.815 & 0.441 & -0.810 & -0.103 \\
\hline Embryo size & -0.601 & 0.344 & 0.452 & 0.718 & -0.730 & -0.229 \\
\hline Number of kernels & -0.925 & -0.013 & -0.525 & 0.640 & -0.933 & 0.222 \\
\hline
\end{tabular}


In the accessions of tenera-type E. guineensis, there was great variation in seed weight, ranging from $0.5 \mathrm{~g}$ in the EGT11 (Congo) accession to $1.4 \mathrm{~g}$ in the EGT10 (Congo) and EGT02 (Yangambi) accessions. LDD values were greater than those of TDD, and the seeds had a slightly elongated form (Table 2). Considering internal morphology, high variability was observed in endocarp thickness, with averages ranging from $0.2 \mathrm{~mm}$ in EGT11 (Congo) to $0.9 \mathrm{~mm}$ in EGT04 (Ivory Coast). This type of oil palm is characterized by bilocular seeds that usually contain two kernels. Embryo size was the characteristic that showed the least variation, with values ranging from $2.1 \mathrm{~mm}$ in the EGT10 (Congo) accession to $3 \mathrm{~mm}$ in the EGT07 (Nigeria-Aba-Calabar) accession.

In the cluster analysis for tenera-type E. guineensis, PCA revealed a proportion of total variability by the first two components of $76.6 \%$. The first component shows a direct correlation among seed weight, kernel diameters (transverse and longitudinal), and seed diameters (transverse and longitudinal); these variables are indirectly related to embryo size (Table 4). In terms of accessions, this contrast differentiates groups A and $\mathrm{B}$ (Figure 1). The second component shows a direct relationship between the number of loci and the number of kernels, which are indirectly related to kernel weight and embryo size. Group B stands out regarding this component, having the highest values for seed weight (Table 4). Therefore, the division into groups follows biometric as well as origin-related parameters. Group A had seeds with a more rounded shape and with very thin endocarps, which could be easily broken when squeezed between the fingers. Group B had heavier seeds with a slightly elongated shape, characterized by the presence of equally elongated kernels; whereas group $\mathrm{C}$ had heavier seeds, probably resulting from endocarps thicker than those found in groups A and B.

The tenera-type E. guineensis accessions present the most distinctive parameters among the evaluated samples: seeds and kernels of reduced size and very thin endocarps, when compared with accessions of E. oleifera and dura-type E. guineensis. Tenera-type E. guineensis plants are hybrids, either naturally or artificially produced by crossbreeding between individuals of the dura type, with thicker endocarp, and between individuals of the pisifera type, without endocarp, resulting in fruit with thinner endocarp than the dura type (Rival \& Parveez, 2005). However,
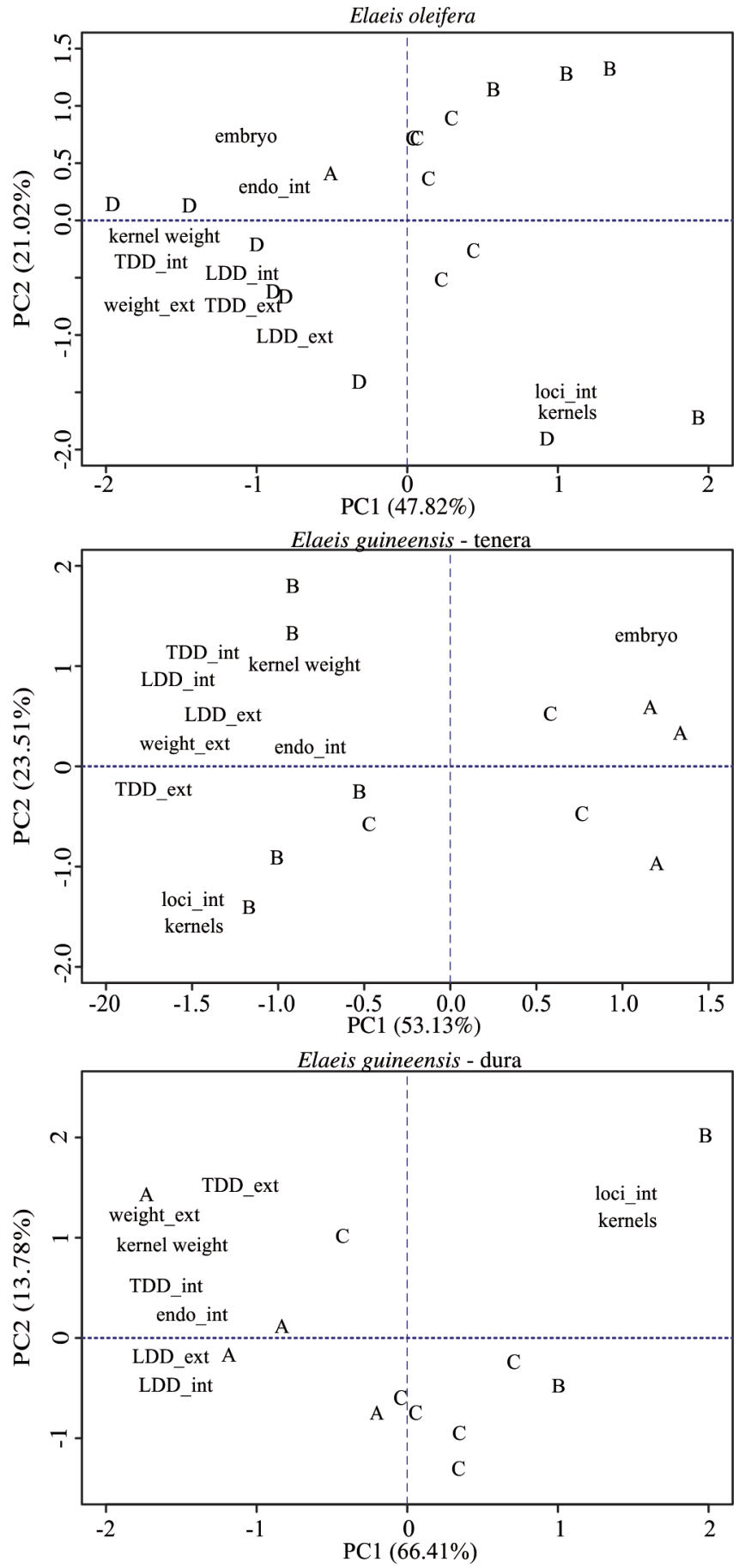

Figure 1. Biplot resulting from principal component (PC) analysis for Elaeis oleifera and E. guineensis, showing the separation among the groups A, B, C, and D formed by cluster analysis (see Table 3). Embryo, embryo size; endo_int, endocarp thickness; kernel_weight, kernel weight; weight ext, seed weight; TDD_int, transversal seed diameter; LDD_ int, longitudinal seed diameter; TDD_ext, transversal kernel diameter; LDD_ext, longitudinal kernel diameter; loci_int, number of loci; kernels, number of kernels. 
variation was observed for this parameter in the E. guineensis types and also in the American oil palm species, E. oleifera, as evidenced by biometric analyses.

Three distinct groups were formed, showing the variability that exists among populations and accessions of the same origin, as can be observed in the accessions originating from Nigeria, Nigeria-Calabar, and Congo. Rajanaidu (1987) reported the existence of variability and morpho-agronomic similarities between tenera material originated from Tanzania and Madagascar. According to the author, one of the most significant variations among the populations was related to fruit weight, which averaged $1.6 \mathrm{~g}$ for the accessions from Madagascar and $8.5 \mathrm{~g}$ for those from Tanzania. This great variability in weight was also observed in the morphological analysis of both seeds and kernels in the present study. The biometric analysis showed high variance in weight, with mean values ranging from 0.5 to $1.4 \mathrm{~g}$ for seeds and from 0.3 to 0.8 for kernels. Similar results were obtained by Akinoso \& Raji (2011) for the tenera type, in which the mean mass of seeds varied between 1.9 and $3.7 \mathrm{~g}$, and that of kernels between 1.1 and $1.7 \mathrm{~g}$, higher than the values registered in the present study. The authors also found that the mean endocarp thickness for the tenera type varies from 0.5 to $2 \mathrm{~mm}$, and that the structure is easily broken with the application of low mechanical compression.

Analysis of the external parameters of accessions of dura-type E. guineensis showed great variability in seed weight, with averages between 2.3 and $5.5 \mathrm{~g}$. Among the assessed materials, this type stands out for having the largest seeds, as shown by TDD and LDD values. The seed shape is elongated, with LDD greater than TDD by at least $3 \mathrm{~mm}$ (Table 2). In the study of internal morphology, endocarp thicknesses ranged from 1.6 to $2.8 \mathrm{~mm}$. The seeds were predominantly bilobular, elongated in shape, containing as many as four kernels, with LDD considerably longer than TDD. Embryo lengths ranged from 1.2 to $3.1 \mathrm{~mm}$, which were the largest embryos of all the evaluated materials. The characteristic kernel weight presented the greatest variation among the accessions - the lightest kernels were observed in the EGD09 accession, with average weight of $0.3 \mathrm{~g}$, and the heaviest, in the EGD04 accession, with average weight of $1.5 \mathrm{~g}$.
In the clusters analysis for dura-type E. guineensis, $80.2 \%$ of the variation was explained by PCA. The first component summarizes all the parameters, with the exception of number of kernels, which is indirectly related with the other ones (Table 4). This contrast differentiates groups A and B from each other, as follows: on average, group A had high values for seed weight and longitudinal seed and kernel diameters; whereas group B showed low values for these same variables, but higher values for number of loci and kernels (Figure 1). The second component shows a direct relationship between the number of loci and the number of kernels. Group A stands out for having lower values, and group B for having higher values for these variables.

The groupings observed for the accessions of dura-type E. guineensis showed lower variability, particularly among those of the same origin. Barcelos et al. (2002) studied the genetic diversity of 38 accessions from the germplasm bank of Embrapa Amazônia Ocidental, using restriction fragment length polymorphism (RFLP) molecular markers, and found that the African group was divided into three subgroups based on origin, of which the group of Deli origin was isolated from the other ones. Morphological analysis of seeds and kernels showed a division of the Deli group into two, with one accession belonging to group A, characterized by heavier kernels and seeds and thicker endocarps, and the other ones to group C, characterized by larger embryo size.

The same division was observed in the groups with origins in Nigeria and in the state of Bahia, Brazil. The closeness between the accessions of African and Brazilian origin is due to the fact that the individuals maintained in Embrapa's germplasm bank, collected in the 1980s from subspontaneous palm groves in the region of Recôncavo Baiano, originate from fruits brought from Africa around the middle of the $18^{\text {th }}$ century (Barcelos et al., 2002). Data obtained in the morphological study of the group of Nigerian origin agree with those reported by Maizura et al. (2006), who, using RFLP markers, found that accessions of dura-type E. guineensis, collected in Nigeria and maintained in germplasm banks in Malaysia, have higher diversity among them, indicating that they may be excellent sources of genes for the enrichment of germplasm collections. The accessions of Bahian origin differ among themselves but display certain 
closeness to those of African origin. According to Barcelos et al. (2002), this may be attributed to the uninterrupted gene flow between populations from Brazil and Africa, whose gene exchanges continued even after the separation of the continents, probably through human action.

The differences observed between the groups from Deli and Ivory Coast origins are in agreement with others studies, which show a significant distance between these populations. Research on diversity suggests that the germplasm of oil palm is structured into three groups (Cochard et al., 2009). The native populations from Africa are genetically structured into two groups from regions separated by the Dahomey Gap, a dry zone that separates regions of equatorial climate forests in Western Africa. Group I is formed by populations from the Ivory Coast, west of the Dahomey Gap, and Group II, by the populations of Benin, Nigeria, Cameroon, Congo, Angola, and other Central African populations. Group III is from Deli origin, derived from Group II as a result of successive cycles of artificial selection following its introduction to Asia. The subspontaneous population of Bahia does not present a distinct genetic structure from the African populations, because, unlike the Deli population, it was not subjected to the selection process.

The results obtained in the present study are important to identify characteristics that can be used in studies of the organization of genetic variability available for oil palm breeding programs. The thickness of the endocarp, for example, a seed characteristic, may be a determining factor in any breeding strategy involving exotic germplasms, since it is specifically from the endosperm that the kernel oil, the second product of importance in oil palm, is produced. The seeds as a bunch component are also associated with the production of oil palm. Therefore, the morphological variability in seeds, besides indicating the high variability in accessions kept in the oil palm germplasm bank of Embrapa, allows the establishment of divergent groups, showing their usefulness for studying the organization of genetic variability.

\section{Conclusions}

1. The variability in oil palm germplasm can be evaluated by seed and kernel morphological characteristics.
2. Elaeis oleifera accessions exhibit morphological variability directly tied to their region of origin.

3. In accessions of tenera-type E.guineensis, individuals are grouped according to their morphological characteristics, with no connection with the region of origin, and the differences between these and the other accessions are associated with the thickness of the endocarp and the shape of the seeds.

4. In dura-type E. guineensis, there is morphological variability among accessions, and those of pisifera and tenera type differ as to seed weight, and kernel number and weight.

5. The variability in the seed characteristics of the analyzed accessions allows the establishment of different groups, which can guide the development of strategies for oil palm genetic improvement.

\section{Acknowledgments}

To Conselho Nacional de Desenvolvimento Científico e Tecnológico $(\mathrm{CNPq})$ and to Financiadora de Estudos e Projetos (Finep), for financial support; and to Coordenação de Aperfeiçoamento de Pessoal de Nível Superior (Capes) and to CNPq, for fellowships granted.

\section{References}

AKINOSO, R.; RAJI, A.O. Physical properties of fruit, nut and kernel of oil palm. International Agrophysics, v.25, p.85-88, 2011.

BARCELOS, E.; AMBLARD, P.; BERTHAUD, J.; SEGUIN, M. Genetic diversity and relationship in American and African oil palm as revealed by RFLP and AFLP molecular markers. Pesquisa Agropecuária Brasileira, v.37, p.1105-1114, 2002. DOI: 10.1590/ S0100-204X2002000800008.

CHRISTRO, L.F.; AMARAL, J.F.T. do; LAVIOLA, B.G.; MARTINS, L.D.; AMARAL, C.F. Biometric analysis of seeds of genotypes of physic nut (Jatropha curcas L.). Agropecuária Científica no Semiárido, v.8, p.1-3, 2012.

COCHARD, B.; ADON, B.; REKIMA, S.; BILLOTTE, N.; CHENO, R.D.; KOUTOU, A.; NOUY, B.; OMORÉ, A.; PURBA, A.R.; GLAZMANN, J.C. Geographic and genetic structure of African oil palm diversity suggest new approaches to breeding. Tree Genetics and Genomes, v.5, p.493-504, 2009. DOI: 10.1007/ s11295-009-0203-3.

CUNHA, R.N.V. da; LOPES, R.; ROCHA, R.N.C. da; LIMA, W.A.A. de; TEIXEIRA, P.C.; BARCELOS, E.; RODRIGUES, M. do R.L.; RIOS, S. de A. Domestication and breeding of the American oil palm. In: BORÉM, A.; LOPES, M.T.G.; CLEMENT, C.R.; NODA, H. (Ed.). Domestication and breeding: Amazonian species. Viçosa: Suprema, 2012. p.275-296.

Pesq. agropec. bras., Brasília, v.49, n.8, p.604-612, ago. 2014 DOI: $10.1590 / \mathrm{S} 0100-204 X 2014000800004$ 
FOOD AND AGRICULTURE ORGANIZATION OF THE UNITED NATIONS. FAOSTAT. Rome: FAO, 2012. Available at: $<$ http://faostat.fao.org $>$. Accessed on: 10 Oct. 2012.

FONDOM, N.Y.; ETTA, C.E.; MIH, A.M. Breaking seed dormancy: revisiting heat-treatment duration on germination and subsequent seedling growth of oil palm (Elaeis guineensis Jacq.) progenies. Journal of Agricultural Science, v.2, p.101-110, 2010.

GOMES JUNIOR, R.A.; GURGEL, F. de L.; PEIXOTO, L. de A.; BHERING, L.L.; CUNHA, R.N.V.; RICARDO, R.; PINA, A.J.A.; VEIGA, A.S. Evaluation of interspecific hybrids of palm oil reveals great genetic variability and potential selection gain. Industrial Crops and Products, v.52, p.512-518, 2014. DOI: 10.1016/j.indcrop.2013.10.036.

LEHMANN, J. Terra Preta de Indio. In: LAL, R. (Ed.). Encyclopedia of soil science. $2^{\text {nd }}$ ed. New York: Taylor \& Francis, 2009. DOI: 10.1081/E-ESS-120045010.

MAIZURA, I.; RAJANAIDU, N.; ZAKRI, A.H.; CHEAH, S.C. Assessment of genetic diversity in oil palm (Elaeis guineensis Jacq.) using Restriction Fragment Length Polymorphism (RFLP). Genetic Resources and Crop Evolution, v.53, p.187-195, 2006. DOI: $10.1007 / \mathrm{s} 10722-004-4004-0$.

MONTOYA, C.; COCHARD, B.; FLORI, A.; CROS, D.; LOPES, R.; CUELLAR, T.; ESPEOUT, S.; SYAPUTRA, I.; VILLENEUVE, P.; PINA, M.; RITTER, E.; LEROY, T.; BILLOTTE, N. Genetic architecture of palm oil fatty acid composition in cultivated oil palm (Elaeis guineensis Jacq.) compared to its wild relative $E$. oleifera (H.B.K) Cortés. Plos One, v.9, p. e95412-e95412, 2014. DOI: 10.1371/journal.pone.0095412.

MORENO-CHACÓN, A.L.; CAMPEROS-REYES, J.E.; DIAZGRANADOS, R.A.A.; ROMERO, H.M. Biochemical and physiological responses of oil palm to bud rot caused by Phytophthora palmivora. Plant Physiology and Biochemistry, v.70, p.246-251, 2013. DOI: 10.1016/j.plaphy.2013.05.026.

MORETZSOHN, M.C.; FERREIRA, M.A.; AMARAL, Z.P.S.; COELHO, P.J.A.; GRATTAPAGLIA, D.; FERREIRA, M.E.
Genetic diversity of Brazilian oil palm (Elaeis oleifera H.B.K.) germplasm collected in the Amazon Forest. Euphytica, v.124, p.35-45, 2002. DOI: 10.1023/A:1015606304653.

MYINT, T.; CHANPRASERT, W.; SRIKUL, S. Germination of seed of oil palm (Elaeis guineensis Jacq.) as affected by different mechanical scarification methods. Seed Science and Technology, v.38, p.635-645, 2010. DOI: 10.15258/sst.2010.38.3.11.

OKWUAGWU, C.O.; OKOYE, M.N.; OKOLO, E.C.; ATAGA, C.D.; UGURU, M.I. Genetic variability of fresh fruit bunch yield in Deli/dura $\mathrm{x}$ tenera breeding populations of oil palm (Elaeis guineensis Jacq.) in Nigeria. Journal of Tropical Agriculture, v.46, p.52-57, 2008.

RAJANAIDU, N. Collection of oil palm (Elaeis guineensis) genetic material in Tanzania and Madagascar. PORIM Bulletin, v.15, p.1-6, 1987.

R DEVELOPMENT CORE TEAM. R: The R Project for Statistical Computing. Vienna: R Development Core Team, 2013.

REY B., L.; GÓMEZ C., P.L.; AYALA D., I.M.; DELGADO A., W.; ROCHA S., P. Colecciones genéticas de palma de aceite Elaeis guineensis (Jacq.) y Elaeis oleifera (H.B.K.) de Cenipalma: características de importancia para el sector palmicultor. Palmas, v.25, p.39-48, 2004.

RIOS, S. de A.; CUNHA, R.N.V. da; LOPES, R.; BARCELOS, E. Recursos genéticos de palma de óleo (Elaeis guineensis Jacq.) e caiaué (Elaeis oleifera (H.B.K.) Cortés). Manaus: Embrapa Amazônia Ocidental, 2012. 39p. (Embrapa Amazônia Ocidental. Documentos, 96).

RIOS, S. de A.; CUNHA, R.N.V. da; LOPES, R.; BARCELOS, E.; TEIXEIRA, P.C.; LIMA, W.A.A. de; ABREU, S.C. Caracterização fenotípica e diversidade genética em subamostras de Caiaué (Elaeis oleifera). Unimontes Científica, v.13, p.49-56, 2011.

RIVAL, A.; PARVEEZ, G.K.A. Elaeis guineensis oil palm. In: LITZ, R.E. (Ed.) Biotechnology of fruit and nut crops. London: Cabi Publishing, 2005. p.113-143. DOI: 10.1079/9780851996622.0113.

Received on April 7, 2014 and accepted on August 7, 2014

Pesq. agropec. bras., Brasília, v.49, n.8, p.604-612, ago. 2014

DOI: 10.1590/S0100-204X2014000800004 